merit. In it were set forth the main tectonic lines, stratigraphy, palæontology and history of this interesting land with its many pre-Cambrian systems, Carboniferous glacials, prolific Permo-Triassic vertebrates and Mesozoic dolerites. During the next decade he carried investigation far to the northto the border of the Kalahari and German territorydescribing little-known pre-Cambrian groups or discovering new ones, such as the crocidolite-bearing jaspers, the Numees tillite, Ongeluk tillite, magmatic copper-bearing eruptives and melilite-basalts.

In the Transvaal, Rogers' main work lay in the mapping of the Heidelberg goldfields, during which the glacials of the Witwatersrand Beds were first recorded. Administrative duties greatly interfered with his output of purely scientific work. Under his able direction, however, a high standard was achieved by the Geological Survey, and numerous maps and memoirs issued, not a few of them of great economic importance.

Attracted, like so many others, by the vast Kalahari and its queer siliceous and calcareous rocks, he was able to cross its heart as well as inspect its borders, and contributed two illuminating addresses on the solid and surface geology of that sand-strewn region.

Always interested in the finer structure of substances, Rogers developed upon retiring to the Cape in 1932 a still keener interest in the microscopical and microchemical examination of the sedimentary rocks, a study which he pursued the more constantly after 1938, when ill-health had debarred him from further field work. To many of us such minuter researches proved helpful indeed.

Rogers' writings were numerous and varied : for the most part accounts of regional geology appearing as departmental reports or in yearbooks, or else as papers based thereon, though none was of monographic size. His most important works are "The Geology of the Country around Heidelberg', his contribution to the "Handbuch der Regionalen Geologie: The Union of South Africa" (1929) and his fascinating history of "The Pioneers in South African Geology and their Work" (1937), in which so much interesting geological as well as biographical information was so meticulously recorded for posterity. His presidential addresses cover a wider field, and range in their subjects from past climates to the eviolution of river systems and 'pans'. Only just recently he completed a description of the diatom floras of the diatomaceous deposits of the Union in collaboration with L. E. Kent, intended for Memoir No. 42 of the Geological Survey, a research on which he had been long engaged.

In all, Dr. Rogers contributed both abundantly and nobly to our geological and geographical knowledge of a wide terrain, which I indeed regard as one of the key regions of the earth.

Connected with many learned societies, he was elected a fellow of the Royal Society of London (1918), the Geological Society of London (1896) and Royal Society of South Africa, as well as honorary fellow, member or correspondent of others. Rogers had been president of the Geological Society of South Africa (1915), of the South African Association for the Advancement of Science (1922), of the Inter national Geological Congress (1929) and of the Royal Society of South Africa (1934-35). His awards were numerous : the Bigsby Medal (1907) and Wollaston Medal (1931) of the Geological Society ; South African Medal (1913) of the South African Association for the Advancement of Science; Scott Medal (1931) of the Biological Society of South Africa, and Draper Memorial Medal (1936) of the Geological Society of South Africa. He received the degree of Sc.D. from Cambridge and an honorary degree of D.Sc from the University of the Witwatersrand.

Rogers will always be remembered for his geniality, readiness to discuss or guide, scrupulous attitude towards the work or views of others, and honesty of purpose. His outlook was, however, coloured by some conservatism. Throughout, he was the man of science pursuing his subject for its own sake, and perhaps for that reason the grander problems of the African continent do not seem to have gripped him. Having been closely associated with Arthur Rogers over many years, I feel that a noteworthy geologist has been lost to the world.

Alex. L. DU TOIT

WE regret to finnounce the following deaths :

Dr. H. A. Colwell, known for his work on X-ray therapy and related subjects, on July 22, aged seyenty.

Prof. J. Park, emeritus professor and formerly dean of the Faculty of Mining in the University of Otago, aged eighty-nine.

\section{$6 / 5$ Social Anthropology at Oxford: Prof. A. R. Radcliffe-Brown}

Prof. A. R. Radcliffe-Brown, who is retiring from the chair of social anthropology in the University of Oxford, took $\mathrm{r}$ Cambridge degree in moral philosophy and shatied anthropology as a post-grad. uate styidn finder Haddon and Rivers, lecturing also oct ithally for the London School of Economics. fiptefed work in the field with a visit to the A $4 \mathrm{~d}$ mins as Anthony Wilkin Student in 1906, but his book on "The Andaman Islanders", in its first form presented as a fellowship thesis at Trinity College, though finished before the First World War, was not published until 1922. By that time RadcliffeBrown had been lecturing on anthropology at Johannesburg and was the first professor of social anthropology at Cape Town. From Cape Town he went as the first holder of a chair of anthropology at

\section{and VIEWS}

Sydney, and his foundation of a school of research and teaching at these two universities has perhaps been the most important contribution to anthropology of his career. His series of very important papers on Australian kinship systems, originally published separately in Oceania, have since been incorporated and published as a single volume. From Sydney he went to Chicago, again as the first professor of anthropology, so that his choice in 1937 to occupy a newly founded chair in social anthropology at Oxford was almost a foregone conclusion.

Prof. Radeliffe-Brown received the Rivers Memorial Medal of the Royal Anthropological Institute for research in the field in 1938; he was president of the Institute in 1939 and 1940 ; he was Frazer Lecturer in Cambridge in 1939; and he was Henry Myers Lecturer at the Royal Anthropological Institute in 1945. His contributions to anthropology in the form of researches on Australian kinship systems 